Some properties of hepatoflavin which were observed with purified but non-crystalline preparations and were mentioned in a recent note ${ }^{7}$ will be reinvestigated with the isolated pigment.

Courtauld Institute of Biochemistry, KURT G. STERN.

Middlesex Hospital Medical School, London, W.1.

Oct. 22.

${ }^{2}$ K. G. Stern, Z. physiol. Chem., 212, $207 ; 1932$.

${ }^{2}$ K. G. Stern, Ber. Deut. Chem. Ges., 66, 555; 1933.

s P. Ellinger and W. Koschara, ibid., 66, 315, 808; 1933.

- R. Kuhn, P. György and T. Wagner-Jauregg, ibid., B6, 317, 576, $1034 ; 1933$.

${ }^{5}$ O. Warburg and W. Christian, Naturwiss., 20, $980 ; 1932$.

${ }^{8}$ R. Bierich, A. Lang and A. Rosenbohm, ibid., 21, 496; 1933.

${ }^{7}$ K. G. Stern and G. D. Greville, ibid., 21, 720; 1933.

\section{Extra Legs on the Tails of Crabs}

During last August a female edible crab (Cancer pagurus) showing an interesting abnormality was brought into the Plymouth Aquarium and Dr. E. J. Allen, the director, very kindly handed it to me for examination. As will be seen from the accompanying illustrations, the abnormal region is the abdomen, which is exceptionally long and wide, and resembles that of a hermit crab in being twisted towards the right, and in that the pleopods are shorter on the right side than on the left. On the sixth abdominal segment (which bears the uropods in most decapods, but in crabs is usually limbless) there is, on the right side, a supernumerary limb composed of a protopodite, a stumpy endopodite and a two-jointed exopodite which ends as a hard, black claw. Although the general plan is thus that of a uropod, the limb resembles a walking leg in the shape of the joints, thickness of the cuticle, hairiness and particularly in the claw, which is better developed than that of any hermit crab.

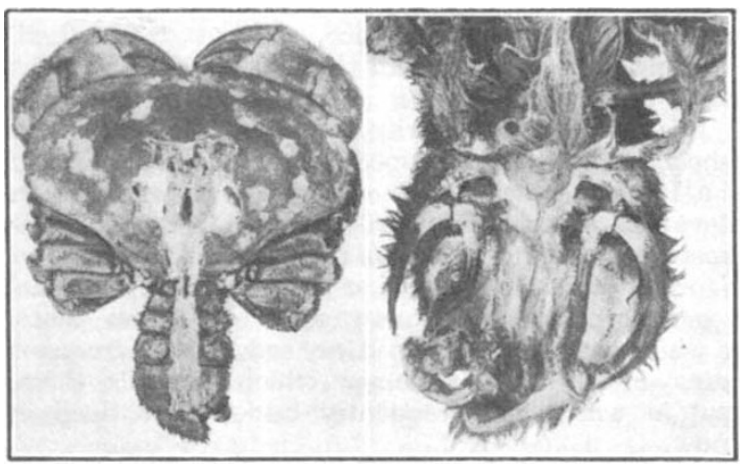

FIG, 1.

There is an interesting case recorded by Bethe ${ }^{1}$ of a similar abnormality in a female Carcinus monas which carried a fully developed walking leg on the left side of the sixth abdominal segment. Bethe did not remark on the size of the abdomen, but from measurement of his illustrations it appears that it was wider, relative to the carapace length, than that of any of the numerous females of this species examined by Huxley and Richards ${ }^{2}$.

Bethe considered that it was impossible to explain his ease on the assumption that differentiation is in any way a function of position: so that he could only conclude that the determinants of form are distributed by unequal cell division and that some cells containing determinants appropriate for a walking leg had become lodged in the tail. The interpretation which can now be given shows in a revealing way the progress which has been made during the intervening thirty-seven years towards an understanding of the factors underlying morphogenesis.

Huxley $^{3}$ has shown that the rates of growth of the segments of the abdomen of female crabs increase progressively passing backwards; that is to say, there is a 'growth gradient' with its apex in the sixth abdominal segment and running in the reverse

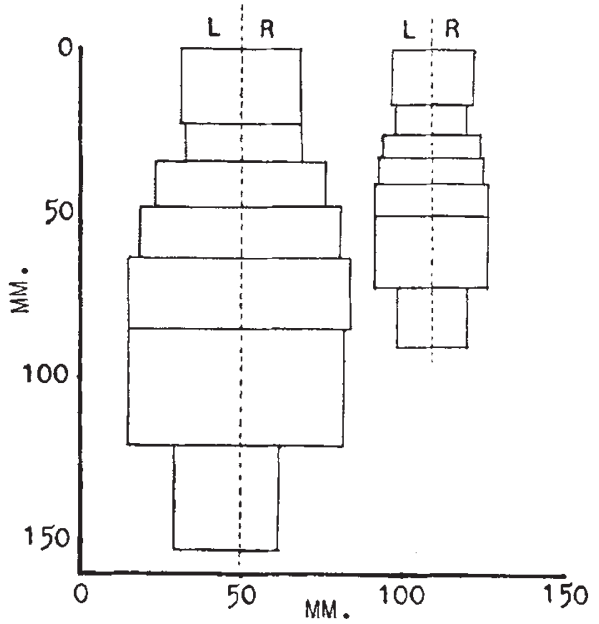

FIG. 2. Comparison of the dimensions of the segments of the abdomen of the abnormal erab here described (left hand figure) and of a normal female specimen of similar size measured by Pearson* (right hand
figure).

direction to the main antero-posterior gradient of the body. He has also collected evidence showing that such growth gradients are connected with those gradients of obscure nature which are established in the early embryo, and thenceforth control morphogenesis. Thus the fact that the abdomen of the two abnormal crabs was unusually wide indicates that the reverse gradient in the tail rose exceptionally steeply, so that the absolute rates of whatever processes are concerned approached the rates usually found in the thorax and caused the supernumerary limbs to develop the characteristics of walking legs.

Department of Zoology and J. Z. Young.

Comparative Anatomy, Oxford. Oct. 15 .

1 Bethe, Arch. Ent. Mech., 3, 301 ; 1896.

2 Huxley and Richards, J. Mar. Biol. Assoc., 17, 1001 ; 1931.

3 Huxley, "Problems of Relative Growth", London 1932.

- Pearson, L.M.B.C. Memoir No. 16. Cancer. London 1908.

\section{Looking Backwards--an Entoptic Experiment}

IN a search for the cause of the visual effects experienced under the influence of Mescal Button, observations were made on entoptic phenomena associated with the retina, and from these it would seem that the human eye can function in a 'verted' as well as in an 'inverted' state: in other words. the sensitive part of the retina can see both ways,

If a microscope is set up to give the best lighting for resolution with the particular objective employed and one eye is applied to the eyepiece, the other 